\title{
Artesunate exerts specific cytotoxicity in retinoblastoma cells via $\mathrm{CD71}$
}

\author{
FEI ZHAO ${ }^{1,2^{*}}$, HAN WANG $^{3 *}$, PATRICILIA KUNDA $^{3}$, XUEMEI CHEN $^{3,4}$, QIU-LING LIU ${ }^{2}$ and TAO LIU $^{3}$ \\ ${ }^{1}$ Graduate Division, Xuzhou Medical College, Xuzhou, Jiangsu 221004; ${ }^{2}$ Department of Pediatrics, \\ The General Hospital of The Chinese People's Armed Police Forces, Beijing 100039; ${ }^{3}$ Poten Biomedical \\ Institute for Cancer Immunotherapy, Shenzhen, Guangdong 518057; ${ }^{4}$ School of Life Science \\ and Technology, Xi'an Jiaotong University, Xi'an, Shaanxi 710049, P.R. China
}

Received April 9, 2013; Accepted May 15, 2013

DOI: $10.3892 /$ or.2013.2574

\begin{abstract}
Retinoblastoma (RB) is an intraocular cancer that affects young children. There is an ongoing effort to find new agents for RB management that are effective, specific and with few side-effects. In the present study, we tested artesunate (ART), a synthetic derivative from the herbal drug artemisinin, used in the clinic for the treatment of malaria. We analyzed ART cytotoxicity in an RB cell line (RB-Y79) and in a retinal epithelial cell line (hTERT-RPE1) by flow cytometric analysis (FCM). We related the effect of ART to the expression of transferrin receptor 1 (TfR-1, also known as CD71) by knocking down CD71 with RNAi and analyzing cell cycle variables by FCM. We found that the cytotoxic action of ART is specific for RB cells in a dose-dependent manner, with low toxicity in normal retina cells. ART is more effective in RB than carboplatin with a markedly strong cytotoxic effect on carboplatin-resistant RB cells. RB had higher CD71 levels at the membrane compared to normal retinal cells. We showed that ART internalization in RB cells is dependent upon the expression of the CD71. In addition, ART blocked the cell cycle progression at the G1 phase, even at low doses, and decreased the proportion of RB cells in the $\mathrm{S}$ phase. In conclusion, we showed that ART is a promising drug exhibiting high selective cytotoxicity even against multidrug-resistant RB cells. Thus, we suggest that ART could be used in the treatment of RB.
\end{abstract}

Correspondence to: Dr Tao Liu, Poten Biomedical Institute for Cancer Immunotherapy, Shenzhen, Guangdong 518057, P.R. China E-mail: tao.liu2008@gmail.com

Professor Qiu-ling Liu, Department of Pediatrics, The General Hospital of the Chinese People's Armed Police Forces, Beijing 100039, P.R. China

E-mail:wj670@vip.sina.com

${ }^{*}$ Contributed equally

Key words: retinoblastoma, artemisinin, transferrin receptor, carboplatin resistant

\section{Introduction}

Retinoblastoma (RB) is the most common intraocular malignancy that affects young children (1-3). It is a rare disease with a 1:15,000/1:20,000 incidence worldwide (4). The mortality rate ranges from 30 to $60 \%$ in developing countries, in opposition to $10 \%$ in other countries such as the USA (4-9). The low survival is due mainly to its late diagnosis $(3,10)$.

Before the 1990's, RB treatment consisted of the removal of the eye and radiation, but the loss of eyes and facial deformity as a consequence of the treatment resulted in severe morbidity for the young patients (11). After the 1990's, chemotherapy became an effective treatment for cancer $(12,13)$. Extensive research has been carried out since then in RB management to save the life and vision of the child. The most common chemotherapy protocol currently in use consists of carboplatin, vincristine and etoposide (14-16). In general, carboplatin is given in 1 day doses (17-19) and is then stopped for several weeks. During this interval, the other anti-neoplastic drugs can be administered. The application of these anti-neoplastic drugs aims to reduce the tumor size (chemoreduction) but a second focal treatment such as cryotherapy or brachytherapy is normally used giving this combined therapy a positive prognosis. Adequate tumor reduction requires 2-6 cycles of chemotherapy (20).

However, the systemic treatment of RB is effective at the beginning of therapy but the long term use of chemotherapy may be limited as these drugs cause serious adverse side-effects, including myelosuppression, ototoxicity, nephrotoxicity and anemia (21-24). In addition, tumor size is reduced by only $3 \%$ after the third chemotherapeutic cycle, compared with a $30 \%$ reduction after the first drug application (25). This suggests that chemotherapy effectiveness in RB patients drops over time, increasing the risk of developing multidrug-resistant RB cells, which increases the chances of tumor re-growth and secondary metastases, thereby limiting the application of chemotherapy in the treatment for RB (26-28). As a result, there is a need for alternative drugs that are effective, selective and with fewer adverse side-effects for RB treatment to overcome the limitations of the current chemotherapeutic drugs.

Artemisinin is a promising drug to test anti-neoplastic activity against RB. Artemisinin is an herbal drug that has been used in traditional Chinese medicine for thousands 
of years (29) and it is clinically used as an anti-malarial drug (30). Artemisinin has low solubility in water or oil, poor bioavailability, and a short half-life in vivo $(30,31)$. However, some semi-synthetic derivatives have been developed, such as artesunate, dihydroartemisinin, artemether and arteether, that overcome the problems associated with the natural product $(30,31)$. In recent years, artemisinin and its derivatives (Arts) have been shown to inhibit cell growth in various types of cancer and cancer cells, such as leukemia, fibrosarcoma, ovarian, breast cancer and cervical cancer cells (32-35). In $\mathrm{RB}$, the cytotoxicity and specificity of these compounds has not been studied. It is a promising drug to test anti-neoplastic activity against RB as Arts induce practically no side-effects and are therefore suitable for a long-term use (36).

Although the underlying mechanism is not clearly known, it is likely that Arts work by a multiple mechanisms dependent on iron (37). Several studies suggested that the antitumor and anti-malarial activities of Arts appear to be exerted through oxidative damage (38), by blocking the cell cycle progression $(35,39)$, by induction of cell apoptosis $(32)$, and others (40). Iron is a key player in the anticancer activity of Arts as it mediates the production of oxidative radicals and, also, as iron metabolism promotes cell growth $(34,36)$. Transferrin receptor 1 (TfR-1, also known as CD71), a type II transmembrane protein, plays important roles in the cellular iron uptake and iron metabolism (41). The expression of TfR-1 in cancer cells is elevated compared to normal tissues, which helps absorb more iron and keep the proliferative profile of the cancer cells $(42,43)$. However, it is not clear whether there is any functional relationship between CD71 and Arts cytotoxicity.

Therefore, Arts may be a good candidate to treat RB. Nevertheless, the ability of these drugs to kill cancer cells is variable and dependent on the tumor cell lines $(33,44)$. It is unknown whether these drugs could have a cytotoxic action on RB cell lines. Therefore, in this study, we analyzed the cytotoxic activity and specificity of artesunate (ART) in an RB cell line, in comparison with its normal counterpart, the epithelial retina cell line. We explored the possible relationship between CD71 and its connection with ART cytotoxicity. In addition, we explored the effect of ART on cell cycle progression in RB cells. We found that the cytotoxic action of ART is specific to RB cells in a dose-dependent manner, with low toxicity in normal retina cells. Markedly, ART exerted high cytotoxicity in carboplatin-resistant RB (RB-R) cells. Also, RB had higher CD71 levels at the membrane than normal retina cells. ART internalization and ART cytotoxic action was dependent, in part, on the CD71 receptor. In addition, ART blocked the cell cycle progression at the G1 phase, even at low doses. In summary, we showed that ART is a promising drug to be used for RB treatment, highly cytotoxic against RB cells and multidrug-resistant cells with limited function in normal retina cells.

\section{Materials and methods}

Antibodies and reagents. ART was purchased from Guilin Pharmaceutical Co.,Ltd.(Guilin, Guangxi, China; H10930195). Carboplatin was purchased from Qilu Pharmaceutical Co. Ltd. (Jinan, Shandong, China; H10920028). ART and carboplatin were freshly prepared and diluted in $5 \% \mathrm{NaHCO}_{3}$ to the required concentrations. CD71-FITC and IgG1-FITC antibodies were purchased from BD Biosciences, USA. Propidium iodide (PI) was purchased from the Beyotime Institute of Biotechnology (Shanghai, China). shRNAs were purchased from Shanghai GenePharma Co., Ltd. (Shanghai, China). Aurum Total RNA Mini kit, iScript cDNA Synthesis kit, iQ SYBR Green SuperMix kit were all purchased from Bio-Rad Laboratories, Inc.

Cell lines. Human RB cell line RB-Y79 was purchased from the American Type Culture Collection (ATCC, Rockville, MD, USA), human retinal pigment epithelium cell line (hTERT-RPE1) was purchased from JENNIO Biological Company (Guangzhou, China). The cells were cultured and passaged advisably in Complete Media (RPMI-1640 medium; Gibco, USA) supplemented with $10 \%$ fetal bovine serum (FBS; Gibco, Australia), 1\% Penicillin-Streptomycin Solution (Gibco, USA) at $37^{\circ} \mathrm{C}$ in a humidified atmosphere of $5 \% \mathrm{CO}_{2}$.

Carboplatin-resistant RB-Y79 cells. RB-Y79 cells in logarithmic phase were incubated with $40 \mu \mathrm{g} / \mathrm{ml}$ at $37^{\circ} \mathrm{C}$ in a humidified $5 \% \mathrm{CO}_{2}$ incubator for $2 \mathrm{~h}$. After centrifuging and washing, the medium containing the drug was discarded. Cells were then cultured in complete culture medium. Once the culture growth was in the logarithmic phase again the carboplatin treatment was repeated. The same procedure was reiterated for several months until a stable resistant cell line at $40 \mu \mathrm{g} / \mathrm{ml}$ carboplatin was generated. To test RB cell resistance to carboplatin, RB-Y79 and RB-R cells were cultured in the presence of $10,20,40,50,60,70,80,90$ or $100 \mu \mathrm{g} / \mathrm{ml}$ carboplatin respectively. After $24 \mathrm{~h}$, cell numbers were counted in the culture using Counter Star with the Automated Cell Counter software (unpublished data).

Cytotoxicity assay. To assess the potential inhibitory capacity of ART, 3x10 ${ }^{4}$ RB-Y79 and hTERT-RPE1 cells were seeded in triplicate in 96-well plates at a density of $1 \times 10^{6}$ cells $/ \mathrm{ml}$. Four hours later, cells were cultured with different concentrations of $\operatorname{ART}(0,12.5,25,50,100$ and $200 \mu \mathrm{g} / \mathrm{ml})$ and carboplatin $(50 \mu \mathrm{g} / \mathrm{ml})$ for 24 and $48 \mathrm{~h}$, respectively. Following collection, cells were washed twice with PBS and stained with PI (final concentration at $1 \mu \mathrm{g} / \mathrm{ml}$ ) for $10 \mathrm{~min}$ in the dark, at room temperature. Cytotoxicity analysis was carried out using the FACSCalibur flow cytometer. Data were analyzed with CellQuest-Pro software, and the percentage of dead cells was calculated. In all experiments the cytotoxic activity was defined as the percentage of dead cells after treatment minus the natural death percentage of the respective cell type. To test the carboplatin cytotoxicity on carboplatin-resistant RB cells, $3 \times 10^{4}$ cells were seeded in triplicate in 96-well plates at a density of $1 \times 10^{6}$ cells $/ \mathrm{ml}$ and cytotoxicity assay was performed by flow cytometry, as explained above.

Membrane CD71 expression assay. To determine the CD71 expression level on cell membrane, RB-Y79 and hTERT-RPE1 cells were seeded in triplicate in T-25 flasks at a cell density of $1.5 \times 10^{6}$. Four hours later, cells were treated with different ART concentrations (final concentration, 0,50 and $100 \mu \mathrm{g} / \mathrm{ml}$ ). After $10 \mathrm{~h}$, cells were washed twice with PBS and incubated with CD71-FITC or IgG1-FITC as control for $30 \mathrm{~min}$ at 
$4^{\circ} \mathrm{C}$, according to the manufacturer's instructions. The CD71 expression levels were tested by FACSCalibur flow cytometry, and $1 \times 10^{4}$ cells were acquired and analyzed for each sample, respectively, using the CellQuest-Pro software. The percentage of CD71 positive cells was defined as the CD71 expression levels.

CD71-RNAi. RB and hTERT-RPE1 cells were seeded in triplicate at $3 \times 10^{5} /$ well in a 6 -well plate. Transfections were performed at $\sim 30-50 \%$ confluency. Cells were incubated in an antibioticfree culture medium for $30 \mathrm{~min}$ before transfection. Cells were transfected with validated shRNAs at $100 \mathrm{nM}$; scrambled shRNA was used as a negative control, GAPDH was positive control shRNA, and 2 CD71 shRNAs (CD71-homo-1569 and CD71-homo-1865), using Lipofectamine ${ }^{\circledR} 2000$ (Invitrogen) according to the manufacturer's instructions. Cells were cultured for $72 \mathrm{~h}$ and used in the following experiments. Silencing was confirmed using quantitative real-time PCR analysis (qRT-PCR). The specific sequences of these shRNAs were: scramble negative control: 5'-UUC UCC GAA CGU GUC ACG UTT-3' and 5'-ACG UGA CAC GUU CGG AGA ATT-3'; GAPDH positive control, 5'-GUA UGA CAA CAG CCU CAA GTT-3' and 5'-CUU GAG GCU GUU GUC AUA CTT-3'; CD71-homo-1569, 5'-GCC CAG AUG UUC UCA GAU ATT-3' and 5'-UAU CUG AGA ACA UCU GGG CTT-3'; CD71-homo-1865, 5'-GGC CAG CAA AGU UGA GAA ATT-3' and 5'-UUU CUC AAC UUU GCU GGC CTT-3'.

Preclusion of off-target effect. The BLAST program is a rapid sequence comparison tool that uses a heuristic approach to construct alignments by optimizing a measure of local similarity. It is widely used for nucleic acid and protein database searches (45). In our experiment, the CD71 shRNAs were blasted in the PubMed database to preclude off-target effect.

Total RNA isolation and real-time PCR analysis. Aurum total RNA mini kit was used to extract total RNA from cells treated with shRNAs according to the manufacturer's instructions; $10 \mu 1$ of total RNA was used for cDNA synthesis by using iScript cDNA synthesis kit according to the manufacturer's instructions. Real-time PCR was performed sequentially by iQ SYBR Green SuperMix kit. The primer sequences were: CD71, forward, 5'-ATCTCGGTCATCAGGATTGC-3' and reverse, 5'-TTAAATGCAGGGACGAAAGG-3'; GAPDH, forward, 5'-CGCATCTTCTTGTGCAGT-3' and reverse, 5'-AATGAAGGGGTCGTTGATGG-3'.

Intracellular concentrations of ART assay. Intracellular ART concentration was performed as described by Okwelogu et al (47). Briefly, 2x107 RB-Y79 cells were seeded in triplicate in T-75 bottle. After $4 \mathrm{~h}$, cells were treated with different concentrations of ART $(0,15,20,25,30,35$ and $40 \mu \mathrm{g} / \mathrm{ml})$. After $24 \mathrm{~h}$, cells were collected and resuspended in $500 \mu \mathrm{l}$ PBS. Repetitive freeze thaw method using liquid nitrogen was used to extract cells, followed by alkaline hydrolysis treatment with $0.1 \mathrm{~mol} / \mathrm{l}$ $\mathrm{NaOH}$ at $83^{\circ} \mathrm{C}$ for $1 \mathrm{~h}$. The UV absorbance value at $237 \mathrm{~nm}$ was then registered by an ultraviolet spectrophotometer. An ART standard curve was drawn under the same conditions. Intracellular ART concentrations were calculated by standard curve (47).
Cytotoxicity assay after CD71-RNAi. To test the cytotoxicity on RB cells, $3 \times 10^{4}$ cells were seeded in triplicate in 96-well plates at a density of $1 \times 10^{6}$ cells $/ \mathrm{ml}$. After $4 \mathrm{~h}$, cytotoxicity analysis was tested by flow cytometry as explained above.

Cell cycle analysis. RB and hTERT-RPE1 cells were seeded in T-25 culture bottle with $5 \times 10^{5}$ cells. After $24 \mathrm{~h}$, cells were treated with different ART concentrations (final concentration, $0,5,10,15$ and $20 \mu \mathrm{g} / \mathrm{ml}$ ) for $24 \mathrm{~h}$. Following collection, cells were washed twice with PBS and fixed with $80 \%$ ice-cold ethanol overnight at $-20^{\circ} \mathrm{C}$. The fixed cells were collected and incubated for $30 \mathrm{~min}$ in PBS containing $50 \mu \mathrm{g} / \mathrm{ml}$ RNase A at $37^{\circ} \mathrm{C}$, stained with $50 \mu \mathrm{g} / \mathrm{ml} \mathrm{PI}$ and $0.2 \%$ Triton X-100 for $10 \mathrm{~min}$ in the dark at room temperature. DNA content analysis were carried out using the FACSCalibur flow cytometer. G0/G1, S, G2/M cell cycle phase were analyzed with ModFit software (Verity Software House, Topsham, ME, USA).

Statistical analysis. All data are presented as means \pm SD. The significance of the difference between groups was evaluated by Paired t-test and one-way repeated measures analysis of variance (ANOVA) and multiple comparisons with SPSS 17.0 software. A value of $\mathrm{P}<0.05$ was considered to indicate a statistically significant difference.

\section{Results}

Specific ART cytotoxicity in the RB cell line. The effect of ART in RB, either in vitro or in vivo, has not been tested. We compared the cytotoxicity of ART in an RB cell line (RB-Y79) vs. a normal retina pigment epithelium cell line (hTERT-RPE1). Several ART concentrations ranging from 12.5 to $200 \mu \mathrm{g} / \mathrm{ml}$ were used and the proportion of dead cell was measured using flow cytometric analysis (FCM) at 24 and $48 \mathrm{~h}$ as described in Materials and methods. At $12.5 \mu \mathrm{g} / \mathrm{ml}$ of ART, $17.5 \%$ of RB cells were dead after $24 \mathrm{~h}$, as shown in Fig. 1A. A similar proportion was observed when $25 \mu \mathrm{g} / \mathrm{ml}$ ART was used. However, the average for RB cell death increased with higher ART doses. After $48 \mathrm{~h}$, the number of RB dead cells increased 2-3 times significantly compared with $24 \mathrm{~h}$ treatment (Fig. 1B). ART killed only a small proportion of hTERT-RPE1 cells, with values slightly higher at $48 \mathrm{~h}$ than those observed with $24 \mathrm{~h}$ ART treatment.

This result shows that ART has a cytotoxic effect in a dosedependent manner against the RB cell line with negligible effect on the normal retina cell line.

$A R T$ cytotoxicity in the carboplatin-resistant $R B$ cells. Carboplatin is one of the chemotherapeutic drugs commonly used for RB treatment in the clinic (14). However, the effective drug concentration used in clinical treatment causes unwanted secondary effects (23). We compared the cytotoxic activity of carboplatin and ART in the RB and hTERT-RPE1 cell lines. We tested the cytotoxicity of $50 \mu \mathrm{g} / \mathrm{ml}$ carboplatin on both cell lines for 24 and $48 \mathrm{~h}(48,49)$. The results showed that only $15 \%$ of RB cells died after $24 \mathrm{~h}$ carboplatin treatment. This proportion was significantly lower than that at the same ART concentration $(\mathrm{P}<0.001)$ (Fig. 1A). After $48 \mathrm{~h}$, carboplatin cytotoxicity increased up to $80 \%$, similar to that observed at the same ART concentration (Fig. 1B). 


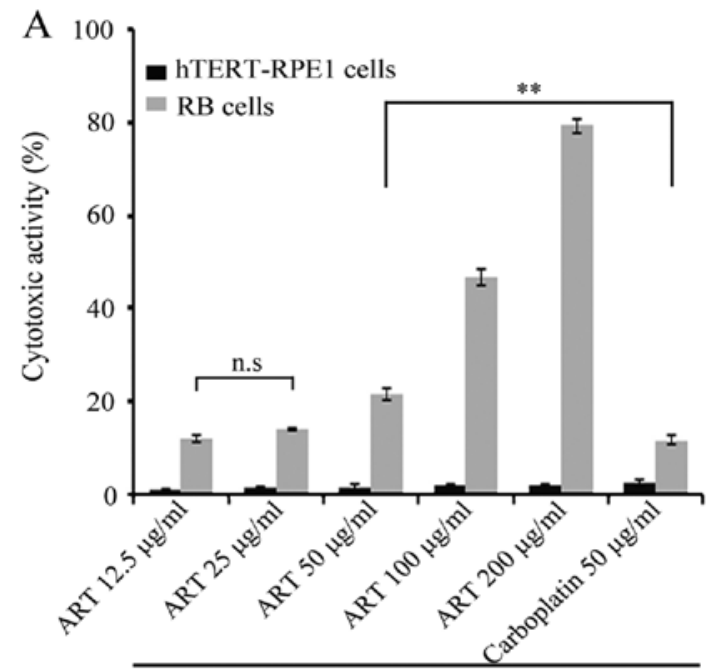

$24 \mathrm{~h}$

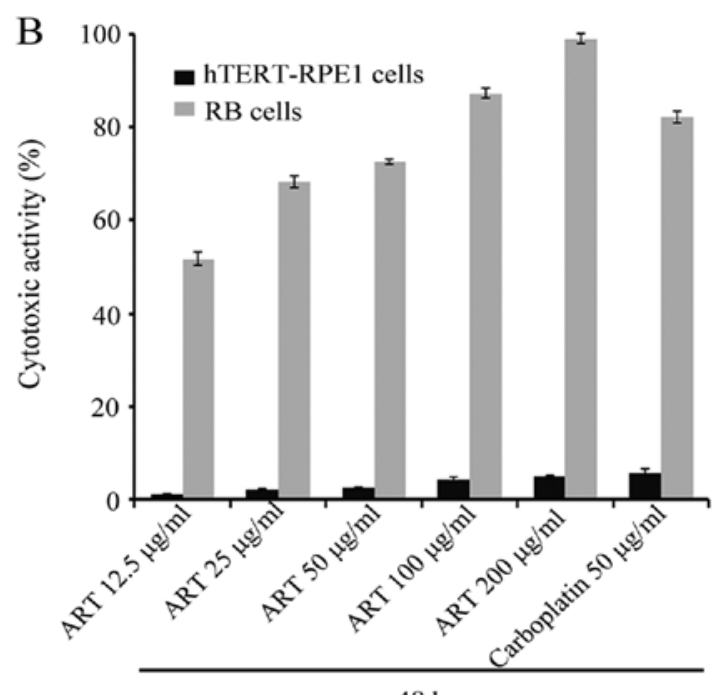

$48 \mathrm{~h}$

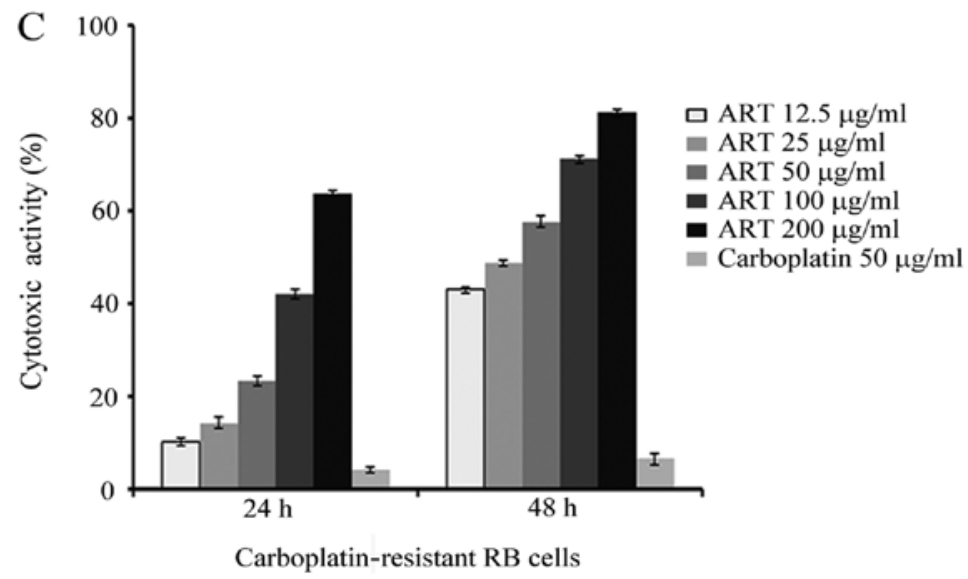

Figure 1. Artesunate (ART) cytotoxicity in retinoblastoma (RB), normal retina and carboplatin-resistant RB (RB-R) cells. (A) RB-Y79 and hTERT-RPE1 cells were treated with different concentrations of ART. After $24 \mathrm{~h}$, cells were stained with propidium iodide (PI) $(1 \mu \mathrm{g} / \mathrm{ml})$ and 10,000 cells were measured respectively by flow cytometry on a BD FACSCalibur. Cytotoxicity is expressed as the percentage of dead cells, relative to the total cell number in the culture corrected by subtracting the natural cell death observed in the untreated control culture. Results are presented as the mean $\pm \mathrm{SD}$ ( $\mathrm{n}=3$, ${ }^{* *} \mathrm{P}<0.01$ ). (B) Cytotoxicity of ART on RB-Y79 and hTERT-RPE1 cells at $48 \mathrm{~h}$. Results are presented as the mean \pm SD (n=3). (C) RB-R cells were treated with different concentration of ART, cells were stained with PI $(1 \mu \mathrm{g} / \mathrm{ml})$ and 10,000 cells were measured respectively by flow cytometry on a BD FACSCalibur. Cytotoxicity at 24 and $48 \mathrm{~h}$ is expressed as the percentage of dead cells, relative to the total cell number in the culture corrected by subtracting the natural cell death observed in the untreated control culture. The percentage of dead cells was calculated compared to the controls treated with the corresponding amounts of medium. Results are presented as the mean $\pm \mathrm{SD}(\mathrm{n}=3)$.

The generation of drug-resistant cells is considered an important factor in the failure of chemotherapeutic cancer treatment. A distinctive characteristic of RB is the fact that it has high expression levels of the drug-resistant proteins that have been suggested to confer resistance (at least in RB cell lines) to drugs used commonly in the clinic for cancer treatment $(21,23,50,51)$. The relationship between the expression of those proteins and the clinical outcome after chemotherapy treatment in RB remains unclear $(50,51)$. Nevertheless, we next explored whether ART was capable of killing RB-R cells. We generated an RB cell line unresponsive to $40 \mu \mathrm{g} / \mathrm{ml}$ of carboplatin in the laboratory (as described in Materials and methods). This cell population was shown to be unresponsive to $24 \mathrm{~h}$ treatment with $40 \mu \mathrm{g} / \mathrm{ml}$ of carboplatin (data not shown). Therefore, we tested the cytotoxicity in RB-R cells at different ART concentrations and $50 \mu \mathrm{g} / \mathrm{ml}$ carboplatin for 24 and $48 \mathrm{~h}$. As shown in Fig. 1C, $\sim 15 \%$ of the RB-R cells were killed by $12.5 \mu \mathrm{g} / \mathrm{ml}$ ART, in contrast to the $5 \%$ cell death observed in
$50 \mu \mathrm{g} / \mathrm{ml}$ of carboplatin treatment. ART cytotoxicity on RB-R cells increased with higher ART concentrations. After $48 \mathrm{~h}$ of treatment, the cytotoxicity was significantly greater with all the ART concentrations tested. However, carboplatin cytotoxicity on RB-R remained low and similar at any incubation time tested (Fig. 1C).

Taken together, our results suggest that ART is effective against RB cells in a dose-dependent manner and, more importantly, it is capable of effectively killing RB-R cells.

Relative CD71 expression levels in RB and hTERT-RPE1 cell lines. We next explored whether CD71 expression was related to ART activity in RB cells. We quantitatively compared CD71 protein expression at the cell membrane in RB and hTERT-RPE1 cells (Fig. 2). The relative level of CD71 (in the absence of ART) in RB cells reached $\sim 70 \%$, displaying values 2 times lower in hTERT-RPE1 cell lines (Fig. 2B). Next, RB and hTERT-RPE1 were incubated with $50 \mu \mathrm{g} / \mathrm{ml} \mathrm{ART} \mathrm{and}$ 

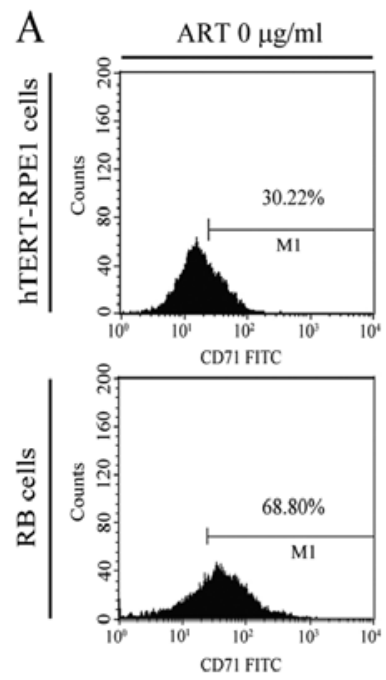
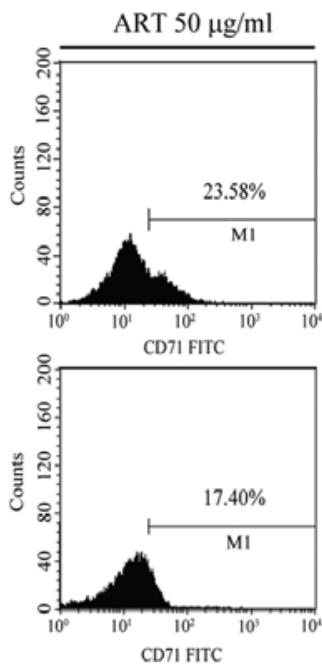
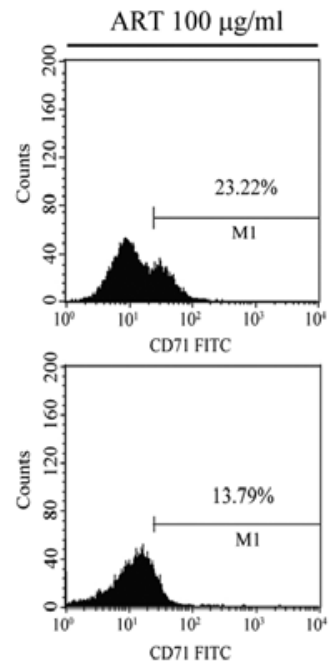

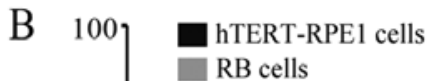

RB cells

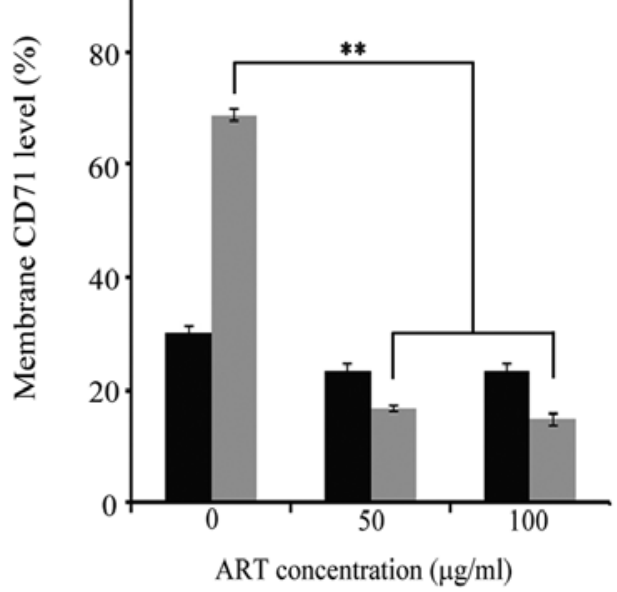

Figure 2. Membrane CD71 expression level in retinoblastoma (RB) Y79 and hTERT-RPE1 cells. (A) RB-Y79 and hTERT-RPE1 cells were treated with different concentrations of artesunate (ART). After $10 \mathrm{~h}$, cells were stained with CD71-FITC and IgG-FITC as isotype control. Ten thousand cells were acquired and CD71 expression was determined by flow cytometry on a BD FACSCalibur. Flow cytometry scatter plots are shown. (B) Membrane CD71 expression in RB-Y79 and hTERT-RPE1 cells was expressed as the percentage of CD71 positive cells relative to cells acquired by flow cytometry compared to the controls treated with the corresponding amounts of medium. Results are presented as the mean $\pm \operatorname{SD}\left(n=3,{ }^{* * *} \mathrm{P}<0.01\right)$.

$100 \mu \mathrm{g} / \mathrm{ml}$ ART for $10 \mathrm{~h}$. We first set up a curve dose response in RB cells and the cytotoxicity was tested at different times ranging from 4 to $24 \mathrm{~h}$ (data not shown). Based on the results, we selected the proper time for the drug to cause $<5 \%$ death. Therefore, we considered $10 \mathrm{~h}$ to be an appropriate length of time for the drug to exert molecular action without killing the cells. The CD71 level at the cell membrane was measured in $1 \times 10^{4}$ cells in any experimental conditions by FCM (Fig. 2). As shown in Fig. 2, ART had no effect on CD71 at the cell membrane in hTERT-RPE1 cell lines. However, CD71 protein at the membrane decreased 4 times when RB cells were incubated with ART, regardless of the dose, as demonstrated by FCM (Fig. 2). These results show that ART induced the CD71 downregulation at the cell membrane in RB cells.

ART internalization depends partly on CD71. In order to get an insight into the specific cytotoxicity in the RB cell line and its relation with CD71, we quantified the intracellular ART concentration. Therefore, we proposed that if CD71 is involved in the internalization of ART, then it would be expected that: i) cells with the highest surface expression of CD71 will have higher intracellular levels of ART, and ii) that suppressing CD71 expression in RB cells will render these cells unresponsive to ART. To verify these, intracellular ART concentration was measured by FCM in RB and hTERT-RPE1 cells after the addition to the media culture of increasing doses of ART ranging from 15 to $40 \mu \mathrm{g} / \mathrm{ml}$. The results showed that intracellular ART in RB cells increased with the extracellular ART dose. However, low levels of ART were found inside the hTERT-RPE1 cell lines (Fig. 3A) regardless of the dose used.

Since both the RB cell line and its normal counterpart, the hTERT-RPE1 cell line, have different levels of CD71 expression at the cell membrane, we further explored whether the CD71 protein expression levels were correlated with ART internalization in the RB cell line. To address this issue, we knocked down CD71 in the RB cell line by using the RNA interference technique (RNAi). We used siRNAs validated by the commercial company (GenePharma Co., Ltd.) and they were blasted in the PubMed database against CD71 to preclude off-target effect. Two non-overlapping shRNAs were used for the CD71 and scramble shRNA was used as a negative control (as explained in Materials and methods). For siRNA validation, we used a quantitative RT-PCR. The qRT-PCR was carried out using the housekeeping GAPDH mRNA in parallel to facilitate comparison with the relative levels of CD71 transcripts purified from RB RNAi-treated cells. After 2 days of siRNA treatment, undetectable CD71 mRNA amplification product was obtained; only a negligible CD71 mRNA amount was detected at a very high cycle number. This result showed that the mRNA knockdown efficiency is acceptable (Fig. 3C and D) under our experimental conditions. The intracellular ART concentration was quantified by FCM in control RNAi and CD71 RNAitreated cells. Intracellular ART increased with higher ART concentration in the culture media in control RB cells but only a low level of ART was found inside the cells in the CD71 knockdown conditions (Fig. 3B). These results suggest that CD71 may be involved in ART internalization.

Specific ART cytotoxicity is mediated by CD71. We next explored whether CD71 was implicated in ART cytotoxicity. Cytotoxicity was evaluated in RB and hTERT-RPE1 cells in both CD71 RNAi and scrambled control conditions (Fig. 3E and F). A low proportion of cell death was observed in control RNAi in hTERT-RPE1 cells, showing values similar to those observed in Fig. 1A at 50 and $100 \mu \mathrm{g} / \mathrm{ml} \mathrm{ART.} \mathrm{No}$ differences in cell death were observed in the CD71 knockdown cells in the 2 ART concentrations tested. Moreover, significantly higher values of cell death were measured in RB cells ranging from 20 to $50 \%$ at 50 and $100 \mu \mathrm{g} / \mathrm{ml} \mathrm{ART}$, respectively, consistent with the data from Fig 1A. Conversely, a significant 2.5 -fold reduction in cytotoxicity was evident in the CD71 RNAi-treated RB cells. These results suggested that 

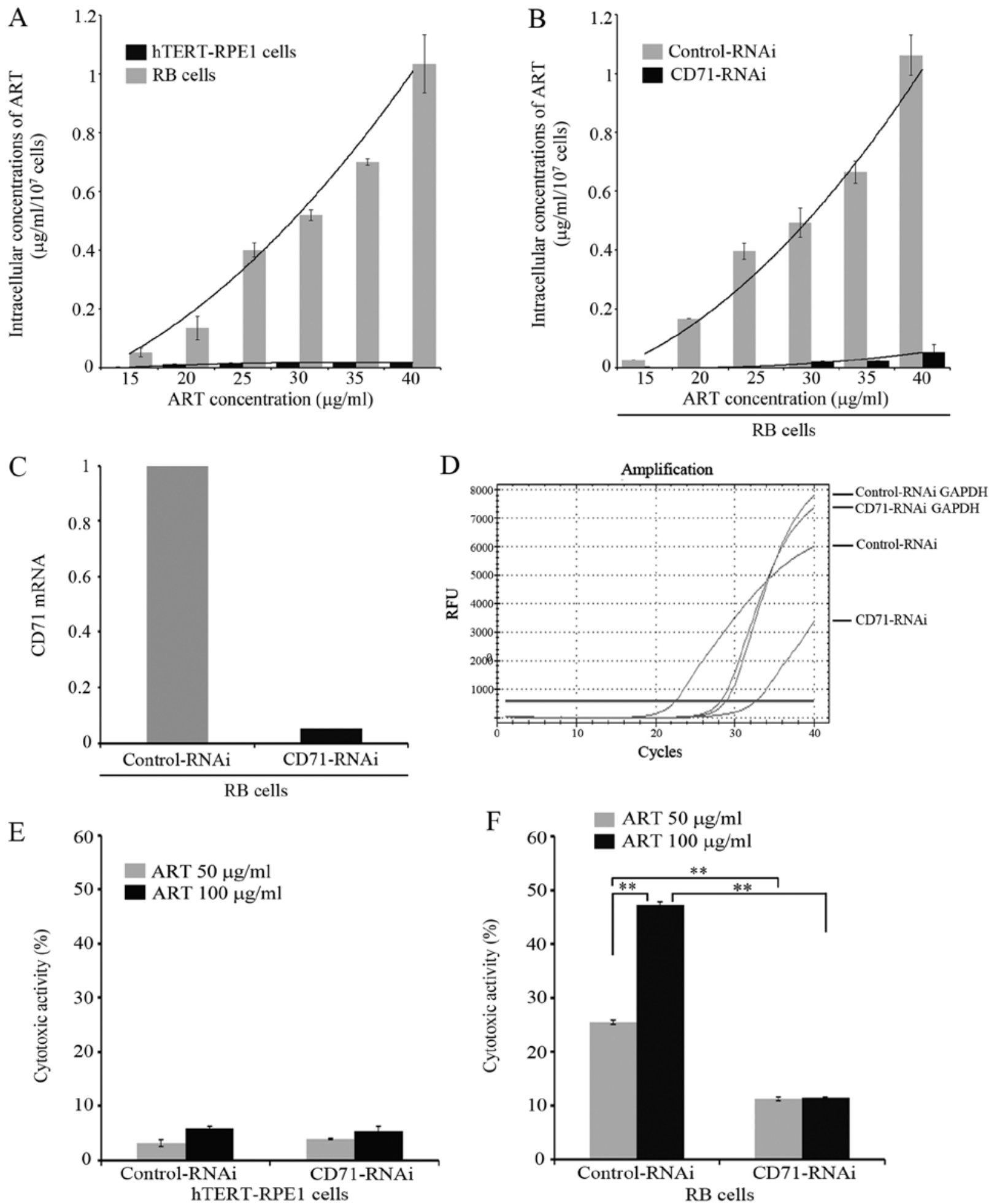

Figure 3. Intracellular concentration of artesunate (ART) and cytotoxicity assay on retinoblastoma (RB) Y79 and hTERT-RPE1 cells after CD71-RNAi. (A) RB-Y79 and hTERT-RPE1 cells were treated with different concentrations of ART. After $24 \mathrm{~h}$, intracellular concentration of ART was determined by ultraviolet spectrophotometer at $237 \mathrm{~nm}$. The intracellular concentration of ART was calculated according to standard curve. Results are presented as the mean \pm SD (n=3). (B) RB-Y79 cells after CD-71 RNAi were treated with different concentrations of ART. After $24 \mathrm{~h}$, intracellular concentration of ART was determined by ultraviolet spectrophotometer at $237 \mathrm{~nm}$. The intracellular concentration of ART was calculated according to standard curve. Results are presented as the mean $\pm \mathrm{SD}(\mathrm{n}=3)$. (C) RB-Y79 cells were transfected with scrambled negative control shRNA, GAPDH positive control shRNA and CD71homo-1569/1865 shRNAs and detected by qRT-PCR. CD71 mRNA level in CD71-RNAi RB-Y79 cells was calculated compared to the controls treated with scrambled shRNA using GAPDH mRNA as control. (D) CD71 mRNA real-time curves of different groups treated with scrambled negative control shRNA, GAPDH positive control shRNA and CD71-homo-1569/1865 shRNAs in RB cells by qRT-PCR were performed. (E) hTERT-RPE1 cells after CD71-RNAi were treated with different concentrations of ART. After $24 \mathrm{~h}$, cells were collected, stained with propidium iodide (PI) $(1 \mu \mathrm{g} / \mathrm{ml})$ and $10,000 \mathrm{cells}$ were measured respectively by flow cytometry on a BD FACSCalibur. Cytotoxicity is expressed as the percentage of dead cells, relative to the total cell number in the culture corrected by subtracting the natural cell death observed in the untreated control culture. Results are presented as the mean $\pm \mathrm{SD}(\mathrm{n}=3)$. (F) RB-Y79 cells after CD71-RNAi were treated with different concentrations of ART. After $24 \mathrm{~h}$, cells were collected, stained with PI $(1 \mu \mathrm{g} / \mathrm{ml})$ and $10,000 \mathrm{cells}$ were measured respectively by flow cytometry on a BD FACSCalibur. Cytotoxicity is expressed as the percentage of dead cells, relative to the total cell number in the culture corrected by subtracting the natural cell death observed in the untreated control culture. Results are presented as the mean $\pm \mathrm{SD}\left(\mathrm{n}=3\right.$, $\left.{ }^{* * *} \mathrm{P}<0.01\right)$. 
ART cytotoxicity could be explained in part by the relatively high CD71 protein expression in the RB cell line.

ART induces G1 phase cell cycle arrest in human RB cells. An association between ART cytotoxicity and cell cycle was previously reported $(35,39)$. We sought to determine whether ART has an effect on cell cycle in RB cells. In order to examine this, we analyzed the cell cycle phases in RB cells and in a normal retina cell line treated for $24 \mathrm{~h}$ with $5,10,15$ or $20 \mu \mathrm{g} / \mathrm{ml}$ of ART. Since we intended to detect any alteration in cell cycle without killing the cells, we used ART concentrations that cause $<10 \%$ cell death after $24 \mathrm{~h}$ of incubation (Fig. 1A). The cell cycle was unaffected by ART in the normal cell line at any drug concentration tested (Fig. 4). Markedly, a G0/G1 arrest was observed when RB cells were incubated with ART at $5 \mu \mathrm{g} / \mathrm{ml}$ (Fig. 4A, D and G) with additional effects at higher ART concentrations (Fig. 4A and G). Moreover, S phase was significantly affected by ART incubation (Fig. 4B and E) depicting values nearly $20 \%$ lower than untreated $\mathrm{RB}$ cells but reaching values similar to the hTERT-RPE1 untreated cells $(\mathrm{P}<0.05)$ (Fig. 4E). ART effect on $\mathrm{S}$ phase seems to be independent of the drug concentration used in the experiment (Fig. 4B). On the contrary, mitotic phase seems to be unaffected regardless of the ART dose used in our assay. These findings suggest that ART has an effect on G0/G1 and S phase but no effect on the $\mathrm{G} 2 / \mathrm{M}$ phase in the $\mathrm{RB}$ cell line.

\section{Discussion}

This study presents evidence, for the first time, that artesunate (ART) exerts a strong and selective cytotoxicity against retinoblastoma (RB). First, we showed that ART cytotoxicity in $\mathrm{RB}$ cells increases in a dose-dependent manner while the same doses cause negligible cell death in normal retina cell lines. Secondly, ART is more effective in RB than carboplatin with a markedly strong cytotoxic effect on carboplatin-resistant RB (RB-R) cells. Thirdly, ART internalization in RB cells is dependent upon the expression of the transferrin receptor (CD71) and, finally, ART influences cell cycle progression by arresting RB cells in $\mathrm{G} 1$ and decreasing the proportion of $\mathrm{RB}$ cells in the $S$ phase.

In 1992, Deng et al (52) first found that artemisinin and its derivatives (Arts) have cytotoxicity in a murine leukemia cell line (P388) (33) and, in the same year, Sun et al (53) found that Arts have cytotoxicity in a human hepatoma cell line (SMMC-7721) and in human gastric carcinoma cells (SGC-7901) but only limited cytotoxicity in the normal embryonic lung cell line (WI-38).

The first evidence of ART antitumor activity was reported by Woerdenbag et al (54) and Yang et al (55). Since then, research has focused on understanding the anti-neoplastic properties of ART. ART has antitumor activity in a wide range of cell lines with variable efficacy from one cancer cell line to another (56). For example, ART seems to be less effective in breast cancer (MCF-7), gastric cancer (MKN) or some prostate cancer cell lines (such as PC-3) $(57,58)$ compared with other cancer cells (59). This study provides the first evidence that ART acts in an RB cell line, and it is specific for RB with a negligible effect on normal retina cells. A comparison of ART vs. carboplatin cytotoxicity showed that ART is active at concentrations similar to those of established antitumor drugs (59). Moreover, this study showed that ART cytotoxicity is higher than carboplatin at the same dose. It has been reported that the Arts are effective against a wide range of resistant cancer cell lines including doxorubicin, methotrexate and hydroxyurea-resistant lines with no cross-resistance $(44,60)$. In the present study we showed that ART is effective in RB-R cells in a dose-dependent manner. These characteristics make ART a suitable candidate as an anti-neoplastic drug for RB treatment.

This study also showed that ART cytotoxicity increases with longer incubation times. However, the serum concentration of Arts declines quickly, with a half-life of the order of an hour (30). Our experimental evidence has been collected in vitro and it is therefore only indicative of the pharmacological behavior of the drug in vivo. The short half-life of ART in serum forces clinicians to administrate the drug at least daily and typically several times a day. For example, the WHO-approved adult dose of ART of $2.4 \mathrm{mg} / \mathrm{kg}$ given at 0,12 and $24 \mathrm{~h}$ for malaria management. Nevertheless, in this study we found a very low cytotoxicity on normal retina cell lines even after $48 \mathrm{~h}$ of ART incubation. Taking into account the long treatment required for cancer management, we cannot preclude a harmful effect on a daily administration during the long period needed to manage an aggressive cancer. However, clinical trials have shown promising results in cancer patients. ART administration to a laryngeal squamous cell carcinoma patient during nine months showed a $70 \%$ tumor reduction prolonging and improving the quality of life of the patient (61).

Sustained proliferation and growth of malignant cells require a high iron metabolism for cell survival and cancer progression (62). Transferrin receptor 1 (CD71) plays a key role in the uptake of iron and regulation of its intracellular concentration $(41,62)$. Most cancer cells exhibit an increment in transferrin receptor expression compared with their normal counterpart. However, CD71 expression levels in cancer cells depend on the cell line. For some cancer cell lines (such as the astrocytoma U373 cell line) the transferrin receptor expression is lower than for others cell lines (such as the leukemia cells, CCRF-CEM), while it is still higher than its normal (non-malignant) counterpart (37,63-65). In the present study, we found that $70 \%$ of the RB cells expressed CD71 protein at the plasma membrane and it is more than 2 times higher than in normal retina cells, suggesting that the CD71 receptor could be a potential target for the ART cytotoxic activity in RB cells.

Accordingly, experiments from other groups showed that the use of a monoclonal antibody directed against the transferrin receptor was able to block artemisinin action in neoplastic cells (37). This raises the question of the functional relationship between ART cytotoxicity and the receptor. It is widely accepted that iron content and metabolism are relevant in the selective antitumor activity of artemisinins $(42,43,66)$. Consistent with this, we showed that ART decreased CD71 levels in the cell membrane. A recent study by $\mathrm{Ba}$ et al (66) showed that CD71 internalization is mediated by the artemisinin-derived compound, DHA, and this internalization may disrupt cellular iron uptake, leading to cell growth arrest and cell death. However, in our study we found that the internalization of ART depends on the CD71 expression and, consequently, it influences the ART cytotoxicity, indicating that ART is internalized by an endocytic pathway together with CD71, 
A

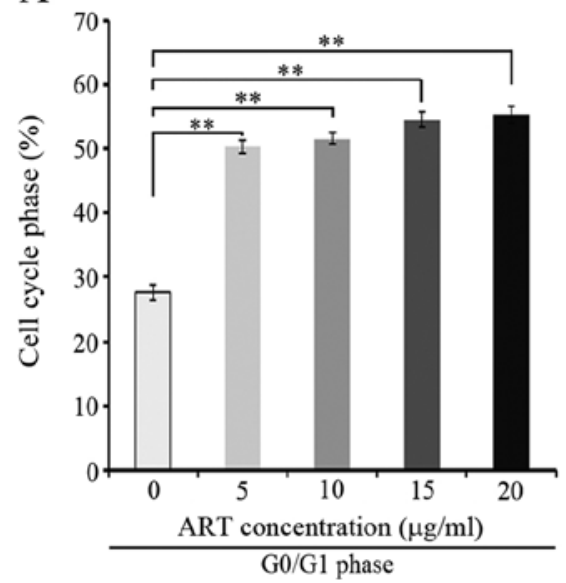

D

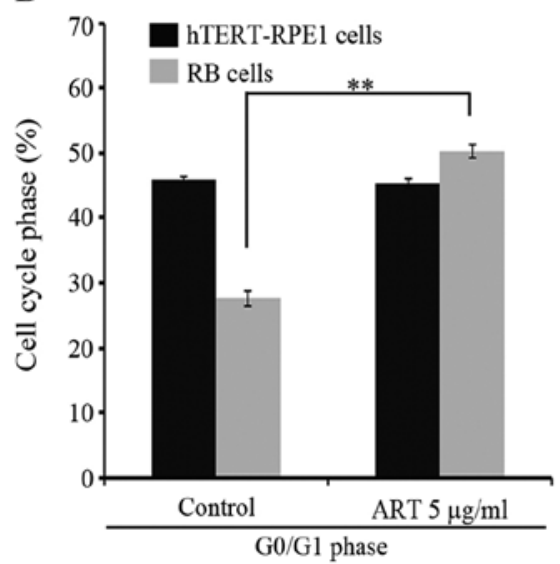

$\mathrm{B}$

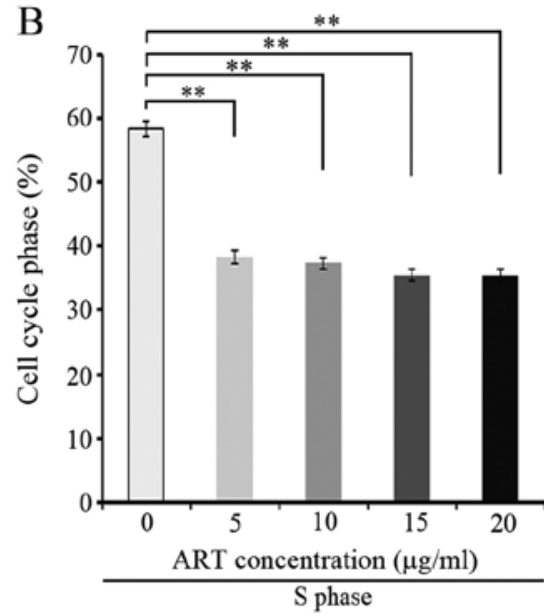

E

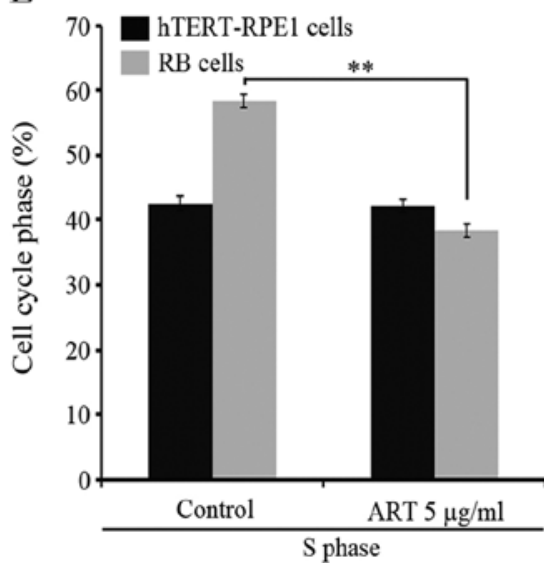

$\mathrm{C}$

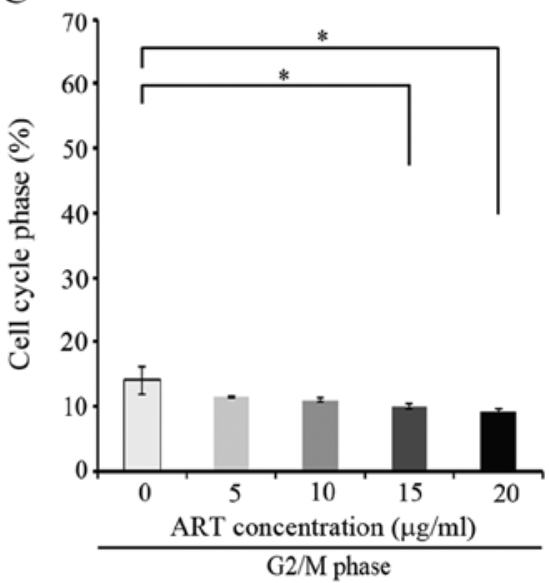

$\mathrm{F}$

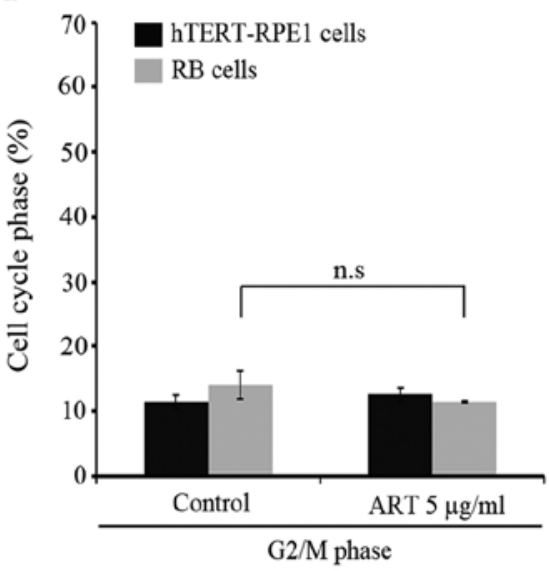

G
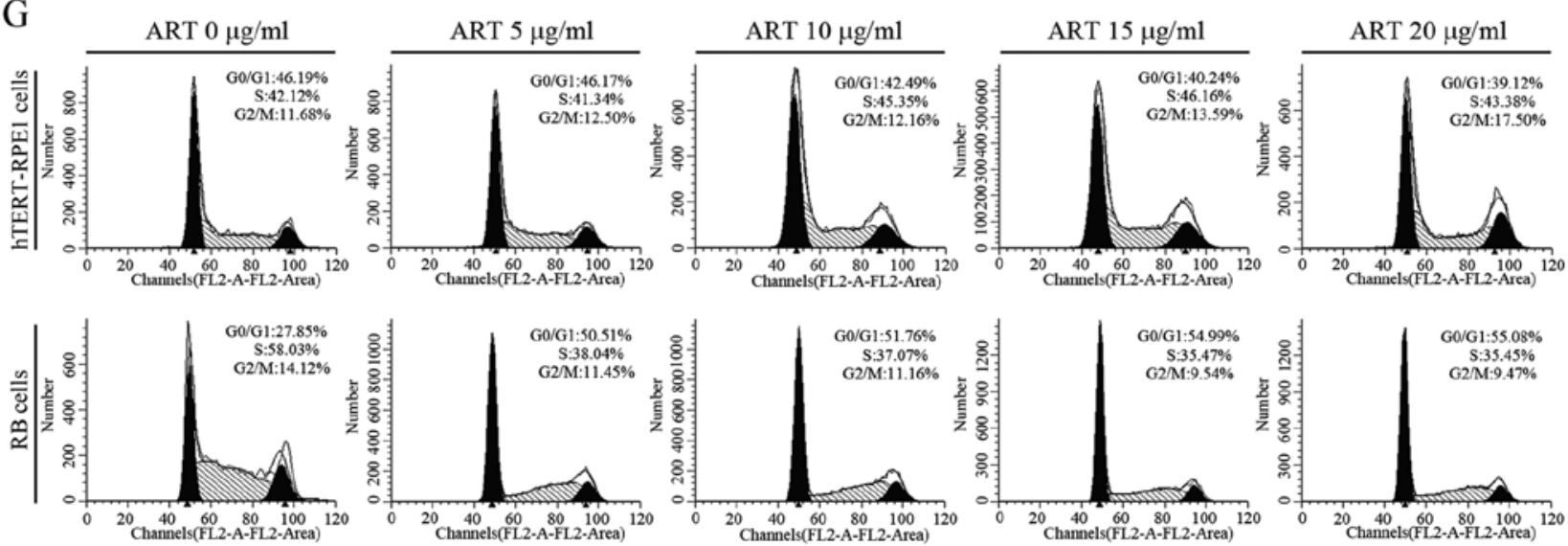

Figure 4. Cell cycle analysis on retinoblastoma (RB) and hTERT-RPE1 cells. (A) RB-Y79 cells were treated with different concentrations of artesunate (ART) for $24 \mathrm{~h} ; 15,000$ cells were acquired and G0/G1 cell phase analysis were detected by flow cytometry on a BD FACSCalibur. The percentage of G0/G1 cell phase was analyzed using ModFit software compared to the controls treated with the corresponding amounts of medium. Results are presented as the mean \pm SD $\left(\mathrm{n}=3,{ }^{* *} \mathrm{P}<0.01\right)$. (B) RB-Y79 cells were treated with different concentrations of ART for $24 \mathrm{~h} ; 15,000$ cells were acquired and S cell phase analysis were detected by flow cytometry on a BD FACSCalibur. The percentage of S cell phase was analyzed using ModFit software compared to the controls treated with the corresponding amounts of medium. Results are presented as the mean $\pm \mathrm{SD}\left(\mathrm{n}=3,{ }^{* *} \mathrm{P}<0.01\right)$. (C) RB-Y79 cells were treated with different concentrations of ART for $24 \mathrm{~h} ; 15,000$ cells were acquired and G2/M cell phase analysis was detected by flow cytometry on a BD FACSCalibur. The percentage of G2/M cell phase was analyzed using ModFit software compared to the controls treated with the corresponding amounts of medium. Results are presented as the mean $\pm \mathrm{SD}\left(\mathrm{n}=3,{ }^{* *} \mathrm{P}<0.01\right)$. (D) RB-Y79 and hTERT-RPE1 cells were treated with $5 \mu \mathrm{g} / \mathrm{ml}$ ART; after $24 \mathrm{~h}, 15,000$ cells were acquired and G0/G1 cell phase analysis was detected by flow cytometry on a BD FACSCalibur. The percentage of G0/G1 cell phase was analyzed using ModFit software compared to the controls treated with the corresponding amounts of medium. Results are presented as the mean $\pm \mathrm{SD}\left(\mathrm{n}=3,{ }^{* *} \mathrm{P}<0.01\right)$. (E) RB-Y79 and hTERT-RPE1 cells were treated with $5 \mu \mathrm{g} / \mathrm{ml}$ ART; after $24 \mathrm{~h}, 15,000$ cells were acquired and S cell phase analysis were detected by flow cytometry on a BD FACSCalibur. The percentage of S cell phase was analyzed using ModFit software compared to the controls treated with the corresponding amounts of medium. Results are presented as the mean $\pm \mathrm{SD}\left(\mathrm{n}=3,{ }^{* *} \mathrm{P}<0.01\right)$. (F) RB-Y79 and hTERT-RPE1 cells were treated with $5 \mu \mathrm{g} / \mathrm{ml}$ ART; after $24 \mathrm{~h}, 15,000$ cells were acquired and G2/M cell phase analysis was detected by flow cytometry on a BD FACSCalibur. The percentage of G2/M cell phase was analyzed using ModFit software comparing to the controls treated with the corresponding amounts of medium. Results are presented as the mean $\pm \mathrm{SD}\left(\mathrm{n}=3,{ }^{* * *} \mathrm{P}<0.01\right)$. (G) RB-Y79 and hTERTRPE1 cells were treated with different concentrations of ART; after $24 \mathrm{~h}$, cell cycle was detected by flow cytometry on a BD FACSCalibur. The percentage of different cell phase was analyzed using ModFit software. Column diagrams are shown. 
probably in a similar way that transferrin is used to internalize iron into the cell (41). If this mechanism is involved in the action of ART, then reducing the expression of CD71 should render the cancer cells unresponsive to ART (since ART will not be internalized and will be rendered ineffective). Knocking down the CD71 receptor by RNAi lowered the cytotoxicity associated to ART, in accordance with Efferth et al (37) who used antibody to block the transferrin receptor (44). However, reducing the CD71 expression did not abolish ART-mediated cytotoxicity in RB. This residual ART cytotoxicity may indicate that the cytotoxicity mediated by CD71 might not be the only mechanism by which ART is internalized and/or exerts its cytotoxic action $(44,67)$. On the other hand, the residual CD71 at the membrane may be sufficient for enough amounts of ART to enter the cell and exert its action.

Finally, in agreement with other studies, low doses of ART are sufficient to alter cell cycle progression (68). RB cells are arrested in the G1 phase according to our data. In addition, the proportion of cells in the $\mathrm{S}$ phase decreased significantly as it is expected if the iron metabolism is affected (44).

Arts may act via multiple mechanisms. The toxicity of artemisinin-related compounds is attributed to iron-mediated oxidative damage by generating reactive oxygen species (ROS) and/or carbon-centered radicals $(69,70)$. Both products may play an important role in inducing DNA damage, mitochondrial depolarization and apoptosis $(40,44)$. Then, cancer cells may suffer more severe damage due to the elevated iron levels that support their high cellular metabolism (71-73). Transferrin receptor plays a key role since it increases the iron level inside the cell. Cancer cells have elevated levels of this receptor at the plasma membrane $(37,74)$. Ba et al $(66)$ showed that in a hepatoma and breast cancer cell line, DHA (an ART derivative) acts through regulating cell-surface TfR-1. They proposed that in the presence of ART, the CD71 receptor is internalized through a non-classical endocytic pathway. In doing so, the iron uptake is altered. We showed here that ART is internalized by the transferrin receptor CD71 (and probably together with the receptor).

We propose that ART uses the CD71 endocytic pathway to be internalized into the cell, reducing CD71 levels at the plasma membrane, therefore blocking iron uptake, damaging the cells by a mechanism independent of oxidative damage. However, our results do not exclude that ART exerts additional cytotoxic actions once it is inside the cell. For example, it has been shown that ART may act on the activation of the mitochondrial intrinsic apoptotic pathway leading to cell death (75), among others (60,76-78).

In summary, the present study showed that ART has a strong cytotoxic effect on RB cells with low cytotoxicity on normal retina cells. We propose that ART is a sound and potentially safe candidate to treat $\mathrm{RB}$. A randomized study in vivo may provide further insight into the efficiency of the treatment.

\section{References}

1. Shields CL and Shields JA: Recent developments in the management of retinoblastoma. J Pediatr Ophthalmol Strabismus 36: 8-18, quiz 35-36, 1999.

2. Shields CL and Shields JA: Diagnosis and management of retinoblastoma. Cancer Control 11: 317-327, 2004.

3. Dimaras H, Kahaki K, O’Dimba EA, et al: Retinoblastoma. Lancet 379: 1436-1446, 2012.
4. Kivela T: The epidemiological challenge of the most frequent eye cancer: retinoblastoma, an issue of birth and death. Br J Ophthalmol 93: 1129-1131, 2009.

5. Bai S, Ren R, Shi J, et al: Retinoblastoma in the Beijing Tongren Hospital from 1957 to 2006: clinicopathological findings. Br J Ophthalmol 95: 1072-1076, 2011.

6. Zhao J, Li S, Shi J and Wang N: Clinical presentation and group classification of newly diagnosed intraocular retinoblastoma in China. Br J Ophthalmol 95: 1372-1375, 2011.

7. Samaila MO: Malignant tumours of childhood in Zaria. Afr J Paediatr Surg 6: 19-23, 2009.

8. MacCarthy A, Draper GJ, Steliarova-Foucher E and Kingston JE: Retinoblastoma incidence and survival in European children (1978-1997). Report from the Automated Childhood Cancer Information System project. Eur J Cancer 42: 2092-2102, 2006.

9. Broaddus E, Topham A and Singh AD: Incidence of retinoblastoma in the USA: 1975-2004. Br J Ophthalmol 93: 21-23, 2009.

10. Chantada G, Fandiño A, Manzitti J, Urrutia L and Schvartzman E: Late diagnosis of retinoblastoma in a developing country. Arch Dis Child 80: 171-174, 1999.

11. Schipper J, Tan KE and van Peperzeel HA: Treatment of retinoblastoma by precision megavoltage radiation therapy. Radiother Oncol 3: 117-132, 1985.

12. Gallie BL, Budning A, DeBoer G, et al: Chemotherapy with focal therapy can cure intraocular retinoblastoma without radiotherapy. Arch Ophthalmol 114: 1321-1328, 1996.

13. Kingston JE, Hungerford JL, Madreperla SA and Plowman PN: Results of combined chemotherapy and radiotherapy for advanced intraocular retinoblastoma. Arch Ophthalmol 114: 1339-1343, 1996.

14. Veal GJ and Boddy AV: Carboplatin dosing in infants with retinoblastoma: a case for therapeutic drug monitoring. J Clin Oncol 30: 3424, 2012

15. Rodriguez-Galindo C, Wilson MW, Haik BG, et al: Treatment of intraocular retinoblastoma with vincristine and carboplatin. J Clin Oncol 21: 2019-2025, 2003.

16. Varan A, Kiratli H, Aydin B, et al: The treatment of retinoblastoma with four-drug regimen including cisplatin, etoposide, vincristine, and cyclophosphamide. Pediatr Hematol Oncol 29: 529-537, 2012.

17. Chantada G, Fandino A, Casak S, Manzitti J, Raslawski E and Schvartzman E: Treatment of overt extraocular retinoblastoma. Med Pediatr Oncol 40: 158-161, 2003.

18. Gao YJ, Qian J, Yue H, Yuan YF, Xue K and Yao YQ: Clinical characteristics and treatment outcome of children with intraocular retinoblastoma: a report from a Chinese cooperative group. Pediatr Blood Cancer 57: 1113-1116, 2011.

19. Leahey A: A cautionary tale: dosing chemotherapy in infants with retinoblastoma. J Clin Oncol 30: 1023-1024, 2012.

20. Shields CL, Kaliki S, Shah SU, et al: Minimal exposure (one or two cycles) of intra-arterial chemotherapy in the management of retinoblastoma. Ophthalmology 119: 188-192, 2012.

21. Chan HS, Lu Y, Grogan TM, et al: Multidrug resistance protein (MRP) expression in retinoblastoma correlates with the rare failure of chemotherapy despite cyclosporine for reversal of P-glycoprotein. Cancer Res 57: 2325-2330, 1997.

22. Gobin YP, Dunkel IJ, Marr BP, Brodie SE and Abramson DH: Intra-arterial chemotherapy for the management of retinoblastoma: four-year experience. Arch Ophthalmol 129: 732-737, 2011.

23. Qaddoumi I, Bass JK, Wu J, et al: Carboplatin-associated ototoxicity in children with retinoblastoma. J Clin Oncol 30: 1034-1041, 2012.

24. Rizzuti AE, Dunkel IJ and Abramson DH: The adverse events of chemotherapy for retinoblastoma: What are they? Do we know? Arch Ophthalmol 126: 862-865, 2008.

25. Abramson DH, Lawrence SD, Beaverson KL, Lee TC, Rollins IS and Dunkel IJ: Systemic carboplatin for retinoblastoma: change in tumour size over time. Br J Ophthalmol 89: 1616-1619, 2005.

26. Marees T, van Leeuwen FE, de Boer MR, Imhof SM, Ringens PJ and Moll AC: Cancer mortality in long-term survivors of retinoblastoma. Eur J Cancer 45: 3245-3253, 2009.

27. Araki Y, Matsuyama Y, Kobayashi Y, et al: Secondary neoplasms after retinoblastoma treatment: retrospective cohort study of 754 patients in Japan. Jpn J Clin Oncol 41: 373-379, 2011.

28. Turaka K, Shields CL, Meadows AT and Leahey A: Second malignant neoplasms following chemoreduction with carboplatin, etoposide, and vincristine in 245 patients with intraocular retinoblastoma. Pediatr Blood Cancer 59: 121-125, 2012.

29. Tu Y: The discovery of artemisinin (qinghaosu) and gifts from Chinese medicine. Nat Med 17: 1217-1220, 2011. 
30. Balint G: Artemisinin and its derivatives: an important new class of antimalarial agents. Pharmacol Ther 90: 261-265, 2001.

31. Chaturvedi D, Goswami A, Saikia PP, Barua NC and Rao PG: Artemisinin and its derivatives: a novel class of anti-malarial and anti-cancer agents. Chem Soc Rev 39: 435-454, 2010.

32. Efferth T, Giaisi M, Merling A, Krammer PH and Li-Weber M: artesunate induces ROS-mediated apoptosis in doxorubicinresistant T leukemia cells. PLoS One 2: e693, 2007.

33. Lai HC, Singh NP and Sasaki T: Development of artemisinin compounds for cancer treatment. Invest New Drugs 31: 230-246, 2013.

34. Gong Y, Gallis BM, Goodlett DR, et al: Effects of transferrin conjugates of artemisinin and artemisinin dimer on breast cancer cell lines. Anticancer Res 33: 123-132, 2013.

35. Gong XM, Zhang Q, Torossian A, Cao JP and Fu S: Selective radiosensitization of human cervical cancer cells and normal cells by artemisinin through the abrogation of radiation-induced G2 block. Int J Gynecol Cancer 22: 718-724, 2012.

36. Kerb R, Fux R, Mörike K, Kremsner PG, Gil JP, Gleiter CH and Schwab M: Pharmacogenetics of antimalarial drugs: effect on metabolism and transport. Lancet Infect Dis 9: 760-774, 2009.

37. Efferth T, Benakis A, Romero MR, et al: Enhancement of cytotoxicity of artemisinins toward cancer cells by ferrous iron. Free Radic Biol Med 37: 998-1009, 2004

38. Berdelle N, Nikolova T, Quiros S, Efferth T and Kaina B: artesunate induces oxidative DNA damage, sustained DNA double-strand breaks, and the ATM/ATR damage response in cancer cells. Mol Cancer Ther 10: 2224-2233, 2011.

39. Li Y SF, Wu JM, Wu GS, Ding J, Xiao D, Yang WY, Atassi G, Léonce S, Caignard DH and Renard P: Novel antitumor artemisinin derivatives targeting G1 phase of the cell cycle. Bioorg Med Chem Lett 11: 5-8, 2001.

40. O'Neill PM, Barton VE and Ward SA: The molecular mechanism of action of artemisinin - the debate continues. Molecules 15: $1705-1721,2010$

41. Hentze MW, Muckenthaler MU, Galy B and Camaschella C: Two to tango: regulation of Mammalian iron metabolism. Cell 142: 24-38, 2010.

42. Shpyleva SI, Tryndyak VP, Kovalchuk O, et al: Role of ferritin alterations in human breast cancer cells. Breast Cancer Res Treat 126: 63-71, 2011.

43. Richardson DR, Kalinowski DS, Lau S, Jansson PJ and Lovejoy DB: Cancer cell iron metabolism and the development of potent iron chelators as anti-tumour agents. Biochim Biophys Acta 1790: 702-717, 2009

44. Crespo-Ortiz MP and Wei MQ: Antitumor activity of artemisinin and its derivatives: from a well-known antimalarial agent to a potential anticancer drug. J Biomed Biotechnol 2012: 247597, 2012.

45. Altschul SF, Madden TL, Schäffer AA, Zhang J, Zhang Z, Miller W and Lipman DJ: Gapped BLAST and PSI-BLAST: a new generation of protein database search programs. Nucleic Acids Res 25: 3389-3402, 1997.

46. Green MD, Mount DL, Wirtz RA and White NJ: A colorimetric field method to assess the authenticity of drugs sold as the antimalarial artesunate. J Pharm Biomed Anal 24: 65-70, 2000.

47. Okwelogu C, Clark B, de Matas M, et al: Design of a fixed-dose paediatric combination of artesunate and amodiaquine hydrochloride. Int J Pharm 387: 19-25, 2010.

48. Calvert AH, Newell DR, Gumbrell LA, et al: Carboplatin dosage: prospective evaluation of a simple formula based on renal function. J Clin Oncol 7: 1748-1756, 1989.

49. Shimokata T, Ando Y, Yasuda Y, et al: Prospective evaluation of pharmacokinetically guided dosing of carboplatin in Japanese patients with cancer. Cancer Sci 101: 2601-2605, 2010.

50. Krishnakumar S, Mallikarjuna K, Desai N, et al: Multidrug resistant proteins: P-glycoprotein and lung resistance protein expression in retinoblastoma. Br J Ophthalmol 88: 1521-1526, 2004.

51. Wilson MW, Fraga CH, Fuller CE, et al: Immunohistochemical detection of multidrug-resistant protein expression in retinoblastoma treated by primary enucleation. Invest Ophthalmol Vis Sci 47: 1269-1273, 2006.

52. Deng DA, Xu CH and Cai JC: Derivatives of arteannuin B with antileukemia activity. Yao Xue Xue Bao 27: 317-320, 1992 (In Chinese).

53. Sun WC, Han JX, Yang WY, Deng DA and Yue XF: Antitumor activities of 4 derivatives of artemisic acid and artemisinin B in vitro. Zhongguo Yao Li Xue Bao 13: 541-543, 1992 (In Chinese).

54. Woerdenbag HJ, Moskal TA, Pras N, et al: Cytotoxicity of artemisinin-related endoperoxides to Ehrlich ascites tumor cells. J Nat Prod 56: 849-856, 1993.
55. Yang XP, Pan QC, Ling YJ, et al: Study on antitumor effect of sodium artesunate. Cancer 16: 186-187, 1997 (In Chinese).

56. Efferth T, Dunstan H, Sauerbrey A, Miyachi H and Chitambar CR: The anti-malarial artesunate is also active against cancer. Int $\mathrm{J}$ Oncol 18: 767-773, 2001.

57. Buommino E, Baroni A, Canozo N, et al: Artemisinin reduces human melanoma cell migration by down-regulating alpha $\mathrm{V}$ beta 3 integrin and reducing metalloproteinase 2 production. Invest New Drugs 27: 412-418, 2009.

58. Morrissey C, Gallis B, Solazzi JW, et al: Effect of artemisinin derivatives on apoptosis and cell cycle in prostate cancer cells. Anticancer Drugs 21: 423-432, 2010.

59. Du JH, Zhang HD, Ma ZJ and Ji KM: Artesunate induces oncosis-like cell death in vitro and has antitumor activity against pancreatic cancer xenografts in vivo. Cancer Chemother Pharmacol 65: 895-902, 2010.

60. Efferth T SA, Olbrich A, Gebhart E, Rauch P, Weber HO, Hengstler JG, Halatsch ME, Volm M, Tew KD, Ross DD and Funk JO: Molecular modes of action of artesunate in tumor cell lines. Mol Pharmacol 64: 382-394, 2003.

61. Singh NP and Verma KB: Case report of a laryngeal squamous cell carcinoma treated with artesunate. Arch Oncol 10: 279-280, 2002.

62. Torti SV and Torti FM: Ironing out cancer. Cancer Res 71: 1511-1514, 2011.

63. Shterman N, Kupfer B and Moroz C: Comparison of transferrin receptors, iron content and isoferritin profile in normal and malignant human breast cell lines. Pathobiology 59: 19-25, 1991.

64. Daniels TR, Delgado T, Rodriguez JA, Helguera G and Penichet ML: The transferrin receptor part I: biology and targeting with cytotoxic antibodies for the treatment of cancer. Clin Immunol 121: 144-158, 2006.

65. Daniels TR, Delgado T, Helguera G and Penichet ML: The transferrin receptor part II: targeted delivery of therapeutic agents into cancer cells. Clin Immunol 121: 159-176, 2006.

66. Ba Q, Zhou N, Duan J, et al: Dihydroartemisinin exerts its anticancer activity through depleting cellular iron via transferrin receptor-1. PLoS One 7: e42703, 2012

67. Eichhorn T, Schloissnig S, Hahn B, et al: Bioinformatic and experimental fishing for artemisinin-interacting proteins from human nasopharyngeal cancer cells. Mol Biosyst 8: 1311-1318, 2012.

68. Zhao Y, Jiang W, Li B, et al: Artesunate enhances radiosensitivity of human non-small cell lung cancer A549 cells via increasing NO production to induce cell cycle arrest at $\mathrm{G} 2 / \mathrm{M}$ phase. Int Immunopharmacol 11: 2039-2046, 2011.

69. Mercer AE, Maggs JL, Sun XM, et al: Evidence for the involvement of carbon-centered radicals in the induction of apoptotic cell death by artemisinin compounds. J Biol Chem 282: 9372-9382, 2007.

70. Mercer AE, Copple IM, Maggs JL, O'Neill PM and Park BK The role of heme and the mitochondrion in the chemical and molecular mechanisms of mammalian cell death induced by the artemisinin antimalarials. J Biol Chem 286: 987-996, 2011.

71. Lai H and Singh NP: Selective cancer cell cytotoxicity from exposure to dihydroartemisinin and holotransferrin. Cancer Lett 91: 41-46, 1995.

72. Lai H, Sasaki T and Singh NP: Targeted treatment of cancer with artemisinin and artemisinin-tagged iron-carrying compounds. Expert Opin Ther Targets 9: 995-1007, 2005.

73. Nakase I, Lai H, Singh NP and Sasaki T: Anticancer properties of artemisinin derivatives and their targeted delivery by transferrin conjugation. Int J Pharm 354: 28-33, 2008.

74. Kwok JC and Richardson DR: The iron metabolism of neoplastic cells: alterations that facilitate proliferation? Crit Rev Oncol Hematol 42: 65-78, 2002

75. Hamacher-Brady A, Stein HA, Turschner S, et al: Artesunate activates mitochondrial apoptosis in breast cancer cells via ironcatalyzed lysosomal reactive oxygen species production. J Biol Chem 286: 6587-6601, 2011.

76. Krishna S, Bustamante L, Haynes RK and Staines HM: Artemisinins: their growing importance in medicine. Trends Pharmacol Sci 29: 520-527, 2008.

77. Kelter G, Steinbach D, Konkimalla VB, et al: Role of transferrin receptor and the $\mathrm{ABC}$ transporters $\mathrm{ABCB} 6$ and $\mathrm{ABCB} 7$ for resistance and differentiation of tumor cells towards artesunate. PLoS One 2: e798, 2007.

78. Hartwig CL, Rosenthal AS, D'Angelo J, Griffin CE, Posner GH and Cooper RA: Accumulation of artemisinin trioxane derivatives within neutral lipids of Plasmodium falciparum malaria parasites is endoperoxide-dependent. Biochem Pharmacol 77: 322-336, 2009. 